\title{
DOSSIÊ
}

\section{Visões sobre o trabalho em transformação ${ }^{1}$}

MÍRIAM DE TON**

Na fase atual, é preciso ousar colocar as questóes para as quais não se tem resposta e levantar problemas cuja solução ainda está para ser encontrada (André Gorz, 1987).

O trabalho permanece como referência dominante não somente economicamente mas também psicologicamente, culturalmente e simbolicamente, fato que se comprova pelas reaçóes daqueles que não o tem (Robert Castel, 1998).

1 Mapeando as mudanças no contexto internacional

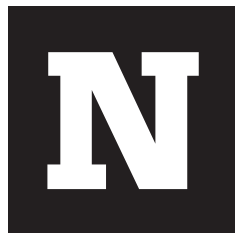

o último quartel do século XX, transformações importantes e profundas passaram a ocorrer em nossas sociedades, fundadas no que tem sido chamado de Terceira Revolução Industrial, ou Revolução da Tecnologia da Informação (Castells, 1999), constituindo-se em um evento histórico interpretado como de mesma envergadura que a Revolução Industrial do Século XVIII. A revolução tecnológica em curso, centrada nas tecnologias

1 A autora agradece às Profas Dras Elida R. Liedke e Maria da Graça Bulhões, do Departamento de Sociologia da UFRGS, e à socióloga Irene $\mathrm{S}$. Galeazzi, técnica da FGTAS-RS, pelos valiosos comentários e sugestões à versão preliminar do texto.

* Técnica, socióloga da Fundação de Economia e Estatística/RS; doutoranda em Sociologia - PPGS-UFRGS. 
da informação, de base microeletrônica, vem remodelando a base material da sociedade e condicionando alterações importantes nas relações entre a economia, o Estado e a sociedade. O sistema social permanece capitalista mas, diversamente de seus predecessores históricos, esse tipo de capitalismo... é global e está estruturado, em grande medida, em uma rede de fluxos financeiros (Castells, 1999, p. 499). Os elementos mais importantes dessa reestruturação podem assim ser caracterizados:

maior flexibilidade de gerenciamento; descentralização das empresas e sua organização em redes tanto internamente quanto em suas relações com outras empresas; considerável fortalecimento do papel do capital vis-à-vis o trabalho, com o declínio concomitante da influência dos movimentos de trabalhadores; individuação e diversificação cada vez maior das relações de trabalho; incorporação maciça das mulheres na força de trabalho remunerada, geralmente em condiçôes discriminatórias; intervenção estatal para desregular os mercados de forma seletiva e desfazer o estado do bem-estar social com diferentes intensidades e orientações, dependendo da natureza das forças e instituiçóes políticas de cada sociedade; aumento da concorrência econômica global em um contexto de progressiva diferenciação dos cenários geográficos e culturais para a acumulação e a gestão do capital(Castells, 1999, p. 21-2).

As mudanças nas formas de produzir e de organizar o trabalho erigemse como estratégias pelas quais o capitalismo busca superar a crise do padrão de acumulação prevalecente em especial no período pós II Guerra Mundial - o fordismo - durante o qual, diferentemente do que se observa na atualidade, o crescimento econômico esteve articulado ao fortalecimento dos movimentos dos trabalhadores e ao desenvolvimento do Estado de Bem-Estar Social. 
A série de reformas desencadeadas no período recente tanto no âmbito das instituições como do gerenciamento empresarial, objetivavam, segundo Castells:

aprofundar a lógica capitalista de busca de lucro nas relações capital-trabalho; aumentar a produtividade do trabalho e do capital; globalizar a produção, circulação e mercados, aproveitando a oportunidade das condições mais vantajosas para a realização de lucros em todos os lugares; e direcionar o apoio estatal para ganhos de produtividade e competitividade das economias nacionais, freqüentemente em detrimento da proteção social e das normas de interesse público (Castells, 1999, p. 36).

Essa reestruturação do capitalismo, empreendida desde os anos 70 entre as sociedades avançadas, ocorre no bojo do processo de globalização - ou da mundialização do capital ${ }^{2}$ - que induz a mudanças qualitativas nos planos produtivo (novas tecnologias e novos padrões de gestão e de organização do trabalho) e político-ideológico (predominância do ideário neoliberal, que coloca o mercado como instância reguladora privilegiada da vida em sociedade). ${ }^{3}$ No âmbito da produção e do trabalho, os novos modelos - japonês, sueco, italiano - constituem alternativas ao modelo fordista clássico, estabelecendo-se como referências para as mudanças nos

\footnotetext{
2 Segundo Chesnais, que prefere esse termo ao de globalização, a "mundialização do capital" é um processo que difere da multinacionalização clássica, característica da internacionalização do capital há mais de um século, e "... designa o quadro político e institucional no qual um modo específico de funcionamento do capitalismo foi se constituindo desde o início dos anos 80, em decorrência das políticas liberalizantes e de desregulamentação das trocas, do trabalho e das finanças, adotadas pelos governos dos países industriais, encabeçados pelos Estados Unidos e a Grã-Bretanha" (Chesnais, 1999, p. 78).

3 Definido de forma abrangente, "O neoliberalismo como formação sócio-econômica é uma configuração de configurações (não é sistêmico; também o caracterizam a contradição, a descontinuidade e a obscuridade). É por um lado uma concepção do mundo, cujo centro se encontra nas teorias da linha genética neoclássica e hoje da escolha racional; é um tipo de política de ajuste macroeconômico, que enfatiza o combate à inflação através da depressão da demanda agregada e uma forma de mudança estrutural das economias dirigida de forma a permitir a 'ação' do livre mercado; é também uma forma de Estado que rompe com os acordos keynesianos e com os pactos corporativos que buscaram conciliar acumulação de capital com legitimidade política do Estado; e, é também uma forma de reestruturação produtiva, conseqüente com a abertura e a globalização das economias, assim como com a ruptura daqueles pactos corporativos" (De la Garza, 1997, p.129).
} 
processos de gestão e de organização do trabalho, notadamente no caso do modelo japonês, ${ }^{4}$ entre os quais a palavra de ordem é flexibilidade.

Inicialmente disseminou-se a crença de que os novos modelos de produção industrial tenderiam a se alastrar para todo o sistema produtivo, apontando para um novo perfil de trabalhador, mais participativo e polivalente, mais escolarizado, com maior soberania no trabalho e cujo conhecimento técnico (o "saber operário") seria valorizado, ensejando novas relações sociais em um processo de humanização do trabalho.

Todavia pesquisas e estudos realizados no interior de grandes empresas, embora constatem mudanças expressivas, produzem evidências que não confirmam a capacidade de esses modelos se tornarem hegemônicos, questionando sua generalização tanto quanto seu caráter virtuoso. ${ }^{5}$ Sucintamente pode-se dizer que, se as transformações têm apontado para a constituição de um segmento de trabalhadores com características próximas ao do "novo trabalhador polivalente", elas também ampliam formas precárias e não-padronizadas de relações de trabalho. Estas últimas decorrem, em parte, do crescente questionamento dos direitos e conquistas trabalhistas, encetado por segmentos representativos do capital e por setores do poder público como elemento que integra as estratégias de enfrentamento da crise, notadamente em seu componente de redução de custos com a mão-de-obra. Como resultados mais gerais desse quadro sobre o conjunto dos trabalhadores, observa-se uma desorganização das relações de trabalho predominantes, especialmente no período pós II Guerra, manifesta através de maior fragmentação e heterogeneidade no mundo do trabalho, multiplicando fontes de insegurança e expondo contingentes expressivos de trabalhadores aos riscos da existência social (Castel, 1998).

4 Para estudos sobre esses modelos ver, entre outros, Coriat, 1994; Wood, 1991; Ferreira et al. 1991 ; Marx, 1992.

5 Dentre os estudos que trabalham essa temática cabe destacar alguns, pelo aporte expressivo de dados bem como por apresentarem um olhar crítico com relação às transformações em curso e suas conseqüências: Capelli et al., 1997, Lipietz, 1988, Coriat, 1994, Castro, 1997, Hirata, 1991, Malaguti, 2000, Marx, 1992, Humphrey, 1995 e Wood, 1991. 
Se tais tendências evidenciadas nos países mais desenvolvidos têm pautado análises de vários cientistas sociais, preocupados com os efeitos nocivos das mutações em curso, é possível afirmar que, nos países periféricos, o quadro é particularmente dramático. Isto porque, diversamente das economias avançadas onde ocorre uma precarização após proteções, persistindo ainda uma rede de proteção social, na periferia, essa proteção social tem sido historicamente insuficiente ou inexistente. Ademais, a crescente precariedade nas formas de inserção no mercado de trabalho, a elevação do desemprego e o relativo desmonte da proteção social sob a responsabilidade do Estado, vêm sobrepor-se a problemas econômicos e sociais preexistentes - o legado histórico de uma estrutura produtiva e de um mercado de trabalho bastante heterogêneos (permanência do setor informal), combinados com a exigüidade dos mecanismos de proteção social (fordismo periférico) e elevados níveis de pobreza. Em uma realidade com tais características, a exclusão social assume proporções alarmantes, podendo atingir até a metade do conjunto das populações desses países. ${ }^{6}$

Dado esse quadro diverso e controvertido, é nossa proposta, neste artigo, sistematizar e discutir as principais abordagens que buscam interpretar os fenômenos emergentes no mundo do trabalho. Não obstante parte considerável delas tenha sido formulada por cientistas europeus e se encontre referida àquele contexto, seu exame tem como objetivo buscar elementos que possam contribuir para se pensar a realidade latino-americana, e a brasileira em particular, seja no que ela tem de semelhante, seja no que apresenta de distinto. O pressuposto aqui não é o de que nossos

\footnotetext{
6 Se considerarmos indicadores de pobreza, na América Latina, em 1990 o número de pessoas vivendo abaixo do nível de pobreza alcançava 204 milhões, ou 40\% da população (Mattoso, 1995). No final dessa década a situação permanecia semelhante, com os $40 \%$ dos domicílios mais pobres captando entre $10 \%$ e $20 \%$ do total da renda gerada. Ainda nos anos 90 , a taxa média de desemprego saltou para $7,2 \%$ da PEA, frente aos $6,6 \%$ dos oitenta, e o setor informal foi responsável por $60 \%$ do total de novos postos de trabalho gerados. No Brasil a situação não é muito distinta: estudo recente do IPEA e IETS revelou que $54 \%$ dos brasileiros vivem abaixo da linha de pobreza (renda inferior a R \$149,00 mensais) e 30\% são indigentes (renda mensal inferior a $\mathrm{R} \$ 73,00$ ) (Zero Hora, 1999); os $40 \%$ mais pobres abocanham somente $10,57 \%$ da renda - a participação mais baixa no continente -, e a taxa de desemprego encontrava-se superior a $7 \%$ no final dos noventa, face à média de $5,3 \%$ para a década anterior. Esses e outros dados podem ser encontrados em La Fuente e Sáinz, 2001 e Stallings e Weller, 2001.
} 
países seguirão os passos das sociedades centrais, numa linha evolutiva à la teoria da modernização, mas que, estando integrados ao sistema capitalista como um sistema-mundo (Wallerstein e Hopkins, 1982) e inseridos no processo de globalização, eles apresentam características que tendem a ser universais, para cujo entendimento e explicação, as visões elaboradas em ambos os contextos podem contribuir. Além disso, a temática em tela vem adquirindo importância crescente, à medida que o processo veloz de difusão tecnológica em voga vem sendo fonte crucial de desigualdade social, desenhando um curso de acontecimentos que pode ser tomado como indicativo de tendências para o futuro próximo e cuja repercussão desfavorável sobre parcelas crescentes de trabalhadores poderá acarretar elevados custos para a sociedade como um todo.

\section{O lugar do trabalho na sociedade contemporânea - um debate controvertido}

As transformações na produção e no trabalho têm recebido interpretações variadas que buscam, a partir da identificação e quantificação das mudanças na estrutura ocupacional e nas relações de trabalho, apreender sua direção e ressaltar suas implicações sociais.

O debate em torno das teses em voga - que compreende desde abordagens que anunciam o fim do trabalho até as que reforçam a centralidade do trabalho, apesar das mudanças que se têm processado em torno dele tem sido intenso e inconcluso, ao mesmo tempo em que tem aportado importantes contribuições e questionamentos para a teoria e a pesquisa nas ciências sociais, notadamente para a sociologia do trabalho. Nesse debate, via de regra toma-se como marco de referência primordial o modelo de sociedade característico do século XX, construído em torno do trabalho, que se encontraria em vias de transformação face à crise do capitalismo do último quartel do século XX. Esse modelo, cujo protótipo se 
estabeleceu em solo europeu, tem recebido diferentes denominações, sendo a mais consagrada a de Estado de Bem-Estar Social, mas também se reconhece pelas denominações de sociedade salarial, fordismo, Estado Providência, dentre outras.

Entre as características principais dessa sociedade destaca-se o fato de associar proteção social e trabalho, cidadania e trabalho, porém, não qualquer tipo de trabalho, mas especificamente o trabalho assalariado, típico do capitalismo. Construído no interior do sistema capitalista de produção, tal modelo visava regular as relações entre o capital e o trabalho, por meio da mediação do Estado, buscando regulações coletivas que se sobrepusessem à estrita relação contratual privada de compra e venda de força de trabalho no mercado, inscrita nos moldes do contrato de trabalho assalariado de cunho liberal, típico do capitalismo em suas fases iniciais. Assim, nos termos da "sociedade salarial", o trabalho passa a ser o fundamento da cidadania econômica tanto quanto o princípio da cidadania social. ${ }^{7}$

Portanto, se o trabalho adquiriu tal centralidade nas sociedades capitalistas, mudanças nessa esfera social devem repercutir de modo importante nos diferentes âmbitos das relações sociais, razão pela qual o papel desempenhado pelo trabalho na organização social passa a ser repensado, redimensionado e questionado. E são precisamente as implicações sociais atribuídas às mudanças nas formas de organizar e de gerir o trabalho, associadas à reestruturação capitalista dos últimos decênios, que os cientistas sociais voltados para as questões do trabalho buscarão evidenciar, no intuito de entendê-las e de explicá-las.

\subsection{Trabalho - a centralidade contestada}

Entre os estudos que têm sido relacionados às teses do "fim do trabaIho", ganham destaque, no contexto europeu, desde o início dos anos 80,

7 Tal fato decorre de que, na situação de trabalho assalariado "O salário reconhece e remunera o 'trabalho em geral', isto é, atividades potencialmente úteis para todos. [Por outro lado, esse trabalho] representa a participação de cada um numa produção para a sociedade e, portanto, na produçâo da sociedade. É assim o ponto médio concreto sobre o qualse constroem direitos e deveres sociais, responsabilidades e reconhecimento, ao mesmo tempo que sujeições e coerções" (Castel, 1998, p. 581). 
os trabalhos de André Gorz e Claus Offe. Esses autores buscaram interpretar as mudanças no mundo do trabalho pela via da perda de centralidade do trabalho como elemento fundante das relações sociais e da construção identitária dos indivíduos, aportando questionamentos para a teoria e a pesquisa nas ciências sociais.

O sociólogo francês, André Gorz, encontra-se entre os pioneiros no tratamento sistemático do questionamento da sociedade centrada no trabalho, a partir da identificação de tendências de redução do emprego industrial nas sociedades capitalistas avançadas, de ampliação de atividades em serviços, de diminuição da jornada de trabalho e de aumento do desemprego e sua manutenção em patamar elevado, frente ao relativo pleno emprego das décadas anteriores. Sua análise encontra-se expressa no livro "Adeus ao proletariado", de 1980, cujo título já enunciava seu posicionamento frente à questão.

Refletindo sobre possibilidades de renascimento de uma esquerda portadora de futuro, não de nostalgia (Gorz, 1987, p. 9), esse autor centra suas colocações no dilema entre a liberdade do tempo e a abolição do trabalho, este entendido como equivalente a trabalho assalariado - emprego. ${ }^{8}$

Dada a evolução das sociedades européias à época, Gorz entendia, por um lado, a impossibilidade de se restabelecer o pleno emprego da era do keynesianismo e, por outro, previa duas formas de gerir a abolição do trabalho, as quais se colocariam no centro das questões políticas dos decênios vindouros: a que leva a uma sociedade do desemprego, e a que leva a uma sociedade do tempo liberado (Gorz, 1987, p. 12). A primeira estaria instalando-se no contexto europeu; a segunda era vislumbrada como alternativa desejável, implicando a superação da lógica capitalista, o enfraquecimento do assalariamento e das relações de mercado. Esta última cons-

8 Para Gorz, "(...) abolir o trabalho não significa... abolir a necessidade do esforço, o desejo de atividade, o amor à obra, a necessidade de cooperar com os outros e de se tornar útil à coletividade". Implica trabalhar menos para viver mais, "poder realizar por si mesmo muitas coisas que o dinheiro não pode comprar e mesmo uma parte das coisas que ele atualmente compra" (Gorz, 1987, p. 11). 
tituiria a sociedade do tempo liberado, em que as atividades autônomas se tornariam preponderantes - não exclusivas - permanecendo, porém, um conjunto de trabalhadores assalariados, identificados e realizados com sua atividade, ligado ao trabalho heterônomo.

Para Gorz, a abolição do trabalho (...) é um objetivo central para aqueles que, não importa o que tenham aprendido a fazer, acham que 'seu' trabaIho [o trabalho capitalista] jamais poderá constituir para eles uma fonte de realização pessoal nem o conteúdo principal de suas vidas (Gorz, 1987, p. 16). A esta parcela de indivíduos, que constituiriam a maioria real ou virtual dos economicamente ativos, esse autor vai chamar de não-classe de não-trabalhadores - o sujeito social (potencial) da abolição do trabalho, portador de futuro.

Ainda nos anos 80, destaca-se a produção do sociólogo alemão Claus Offe, arrolando várias razões que fundamentariam sua tese de que o trabalho, objetivamente, estaria perdendo seu status de fato da vida, sendo privado, também, de seu papel como força subjetiva motivadora central da atividade dos indivíduos. Em seu texto clássico sobre o assunto, que leva como título a pergunta "Trabalho: a categoria chave da sociologia?" (1989), a resposta tende para uma negativa. O autor parte do reconhecimento de que, na tradição clássica da sociologia burguesa e da sociologia marxista, a sociedade moderna e sua dinâmica central se constroem como uma sociedade do trabalho.

Em função da evolução e das configurações que caracterizam as sociedades atuais, Offe postula a implosão da categoria trabalho na constituição da identidade dos trabalhadores. O autor baseia sua avaliação em fatores como: a erosão de tradições culturais; a diminuição do tempo dedicado ao trabalho; a expansão do trabalho em serviços; a descontinuidade profissional; e o aumento do desemprego estrutural, que propiciaria o surgimento de subculturas passivamente hostis aos valores e normas da sociedade do trabalho (economia informal, subterrânea, etc.). Seu questionamento ao trabalho funda-se nos seguintes elementos: 1) o traba- 
Iho deixa de ser tratado como o mais importante princípio organizador das estruturas sociais, dado que as pesquisas voltam-se para a vida cotidiana, fora da esfera do trabalho; 2) a vasta heterogeneidade empírica do trabaIho, a partir da qual o fato de ser um empregado, ou da dependência em relação ao salário, não mais constituiria foco da identidade coletiva e da divisão social e política; 3) o declínio da ética do trabalho, à medida que, no nível da integração social, o trabalho como um dever humano ético está provavelmente se desintegrando; e, 4) o trabalho vem perdendo sua característica de se colocar como uma necessidade, ao nível da integração ao sistema.

A conjunção desses fatores apontaria para uma crise da sociedade do trabalho, o que, agregado à expansão dos serviços, daria origem à chamada sociedade de serviços pós-industrial. Tal realidade ensejaria a emergência de novas teorizações no campo das ciências sociais, voltadas para o domínio da forma de vida fora da esfera da produção - o mundo da vida cotidiana, ação comunicativa, produção doméstica, modos de vida, sociedade pós-industrial.

Mais recentemente, já na década de 90, estudos de outros cientistas vêm ampliando o leque de discussão neste campo, sobressaindo trabalhos como o de Jeremy Rifkin, para os Estados Unidos, o do sociólogo alemão Ulrich Beck e o da filósofa francesa Dominique Méda, cuja relevância repousa na abrangência de suas abordagens, tanto quanto no destaque de que elas vêm sendo alvo.

Rifkin parte da experiência da sociedade norte-americana e visualiza um futuro sombrio, caso o evolver da Terceira Revolução Industrial siga o rumo indicado pela evolução recente do mercado de trabalho. Isto porque, na busca frenética por aumentos de produtividade, de competitividade e de melhores margens de lucro em um mundo globalizado, as empresas têm privilegiado estratégias calcadas em redução de custos com mão-de-obra, provocando queda do emprego formal de tipo fordista, elevação do desem- 
prego e expansão de empregos precários. ${ }^{9}$ Em obra largamente conhecida O fim dos empregos (1995) - o autor afirma que, na Era da Informação e da revolução da alta tecnologia, desenha-se um mundo sem trabalhadores, com o fim do trabalho formal em massa, e no qual as máquinas são o novo proletariado. Para ele, isso ocorre porque, ao contrário de outros momentos de grandes inovações tecnológicas na história, em que a substituição de trabaIhadores em certos setores era compensada pela ampliação do trabalho em outras áreas da atividade econômica, atualmente as transformações atingem todos os setores. Isto é, o deslocamento tecnológico é vivenciado em todas as áreas da produção, forçando o declínio sistemático e inevitável dos empregos e o aumento do desemprego, até porque o único setor emergente - o do conhecimento - emprega apenas pequena elite de trabalhadores. Em decorrência, amplia-se o contingente de trabalhadores deslocados e as novas funções que se criam envolvem geralmente empregos temporários e de baixa remuneração, reduzindo-se as perspectivas de encontrar "bons empregos", em um mundo cada vez mais automatizado.

Diante desta mágica da tecnologia, incapaz de criar novos empregos em número significativo, o resultado mais visível é o elevado desemprego tecnológico provocado pelas grandes empresas e, em decorrência, um aumento da precarização das relações de trabalho, expansão do contingente de pobres e maior desigualdade de renda para o conjunto da sociedade norte-americana. Como resultado, ampliar-se-á a exclusão social, enquanto os trabalhadores que permanecerem empregados verão a jornada de trabalho reduzida e o tempo livre aumentado.

Como alternativa a essa trajetória que, segundo o diagnóstico de Rifkin, levaria a sociedade americana a uma crise econômica e social, o autor propõe a busca de um novo contrato social, no qual a reprodução social se basearia em uma nova forma de trabalho, não mais definida em valores individuais e materiais. A solução encaminhada, como última e melhor

9 Para embasar sua análise Rifkin apresenta ampla gama de dados sobre a evolução do mercado de trabalho, especialmente nos EUA. Veja-se Rifkin, 1995. 
esperança, direciona para a expansão do trabalho no terceiro setor, capaz de absorver a enchente de trabalhadores deslocados, preenchendo, assim, parte do tempo livre dos empregados e o tempo ocioso dos desempregados. Resgatando a tradição de trabalho voluntário existente nos Estados Unidos (pesquisa realizada no início dos anos 90 atestava que $51 \%$ dos americanos doavam parte de seu tempo a várias causas ligadas a organizações voluntárias), Rifkin enfatiza a necessidade de o governo e a sociedade darem mais atenção ao terceiro setor, como alternativa para o desenvolvimento de atividades fora dos setores público e privado, baseadas na vida comunitária, para além do mercado.

A argumentação avançada por Beck apresenta elementos comuns à análise de Rifkin. Assim, como ponto inicial, afirma que estamos nos encaminhando para um capitalismo sem trabalho - e isso em todas as sociedades pós-industriais do Mundo (Beck, 1997, p. 42). Em sua visão, a tradicional sociedade do trabalho, com seus life-long jobs (empregos que perduravam por praticamente toda a vida ativa do trabalhador), vem sendo suplantada por um mundo muito menos estável no qual habilidades, postos de trabalho ou direitos do trabalho podem ser rapidamente eliminados ou reduzidos. Uma crescente insegurança na vida dos trabalhadores e a ameaça de exclusão social são as marcas características deste globalismo neoliberal, ${ }^{10}$ que tende a conformar uma estrutura social de ambigüidade e atividades múltiplas, típica dos países em desenvolvimento, o que leva o autor a caracterizar o fenômeno como uma brasilianização do oeste, no contexto de um regime de risco (Beck, 2000). ${ }^{11}$

\footnotetext{
10 Beck coloca como diferença essencial entre a primeira e a segunda modernidades o caráter irreversível da globalidade, no final do século XX. "Isto significa que vivemos em uma sociedade mundial politicamente multidimensional, policêntrica e contingente, na qual agentes transnacionais jogam de gato e rato" (Beck, 1998, p. 163). Essa globalidade complexa difere do "globalismo neoliberal", que simplifica e reduz a globalidade a um só aspecto - o econômico - defendendo a primazia e a imposição do mercado mundial, que impregna todos os aspectos e a tudo transforma. Para uma exposição do globalismo e crítica às suas falácias veja-se Beck (1998).

11 Segundo o autor, essa expressão define a sociedade atual - a Segunda Modernidade. Nela, o regime de risco prevalece em todos os campos, como um princípio chave, tendo como traços básicos a insegurança, a incerteza e a perda de fronteiras nas várias áreas da vida social. Quanto ao trabalho, envolve uma individualização das relações e a mudança na forma biográfica e legal, anteriormente padronizada, para o risco desregulado.
} 
Todavia Beck não compartilha de teses que prenunciam catástrofes face ao desaparecimento do trabalho produtivo da sociedade industrial. Crê que, se corretamente orientada - e veja-se que esta é uma condição prévia difícil de definir e implementar - a substituição parcial ou total de trabalho por produção automatizada pode abrir oportunidades de liberdade enormes, à medida que a produção de mais riqueza com menos trabalho pode tornar factível o velho sonho de livrar a humanidade do jugo do trabalho. Como estratégias de uma modernização reflexiva, o autor considera a necessidade de reformas políticas e sociais que contemplariam o direito de cada um a ser incluído em uma nova definição e distribuição do trabalho - que envolveria movimentos constantes entre emprego formal (com importante redução da jornada de trabalho) e formas de trabalho público, isto é, atividades artísticas, culturais e políticas auto-organizadas e uma proteção social compreensiva. Esta última compreenderia uma garantia de mínimos, em função das necessidades, que complementaria a seguridade básica ante riscos massivos, transformando assim a insegurança associada à descontinuidade de vida em algo positivo e enriquecedor. Entre suas propostas destaca-se a elaboração de um novo contrato social, que fundamente a democracia em um mundo além da sociedade centrada no trabalho, de plena ocupação, e a formação de um novo centro de atividades e de identidade, que vivifique a forma democrática de vida: "trabalho público" (Beck, 1997, p. 48). Na acepção do autor, o trabalho público criaria novos centros de ação e identidade políticas em meio à sociedade fragmentada e contra ela (Beck, 1997, p. 49), constituindo-se em um trabalho que implica compaixão ativa, crítica prática e democracia ativa.

Dominique Méda, desde um enfoque filosófico, norteia seu trabalho no sentido de fundamentar uma crítica à idéia de que a atividade produtiva e, portanto, o trabalho, englobaria o conjunto das atividades humanas necessárias à satisfação e realização pessoal e social, em toda sua diversidade e riqueza. 
Após exaustiva sistematização dos vários significados atribuídos ao trabalho no decorrer da história, Méda (1999) conclui que, no alvorecer do século XX, não se trata mais de sonhar a essência do trabalho - como proposto por Marx - mas de tornar suportável o trabalho real. Esse século já não é o do trabalho mas o do emprego. O emprego é o trabalho assalariado em que o salário já não é apenas a estrita contrapartida da prestação de trabaIho, mas também o canal de acesso dos assalariados à formação, à segurança, aos bens sociais (Méda, 1999, p. 141).

A partir deste entendimento, Méda critica o argumento de que o trabalho estaria no fundamento do laço social. Afirma que o trabalho exerceria as funções de laço social apenas por acidente, uma vez que não foi inventado com o fim de reunir os indivíduos em torno da realização de uma obra comum (Méda, 1999, p. 174). Reconhecendo que o trabalho é um meio de aprender a vida em sociedade, de encontrar os outros e de socialização do indivíduo, afirma que ele assim o é apenas de forma derivada.

Todavia considerando o lugar que o trabalho acabou assumindo em nossas sociedades, Méda vai propor a redução do tempo de trabalho individual como a condição sine qua non do desenvolvimento de outros modos de sociabilidade - a par da produção; de um verdadeiro espaço público e de um tempo livre, fora da esfera da produção, para consagrar a outras atividades. Esta questão toca em um dos pontos fundamentais de sua argumentação, qual seja, a redução do tempo de trabalho e, tão ou mais importante que isso, a partilha do trabalho. Se, em nossos dias, o trabalho constitui o principal meio de distribuição dos rendimentos, dos estatutos, da proteção e das posições sociais, rever a maneira como se partilha o trabalho leva a repensar também a repartição do conjunto dos bens sociais (Méda, 1999, p. 318). Isto porque tal repartição não é mera questão econômica, uma vez que põe em jogo a nossa concepção de sociedade. Nesse sentido, Méda condena a partilha que se faz hoje do trabalho, a qual se efetua através de exclusão de certos grupos de indivídu- 
os do mercado de trabalho, do alongamento da jornada de trabalho para outros e da forte seletividade do mercado de trabalho. Afirma que a nossa partilha opera-se através de um despejo na categoria do desemprego (Méda, 1999, p 320).

Propõe, em termos de ideal normativo, uma sociedade plenamente ativa [que] assegure a cada indivíduo acesso a todo o espectro de atividades humanas (...) atividades políticas, produtivas e culturais, tanto quanto atividades privadas (Méda, 1996, p. 642). Colocando como principais problemas para a sociedade atual o déficit democrático tanto quanto o déficit de emprego, propugna uma nova noção de pleno emprego, que significa que cada um tem acesso ao emprego sobre uma base justa e eqüitativa, mas que esse emprego ocupa um menor número de horas, deixando a todos espaço e tempo para dedicar a outras atividades, privadas e coletivas (Méda, 1996, p. 643).

As abordagens acima examinadas, embora tenham em comum o fato de enfocar as transformações recentes como prenúncio do fim do trabaIho, apresentam nuanças na análise de seus impactos bem como nas direções propostas ou imaginadas para o futuro das sociedades.

Gorz e Offe, nos primórdios desse debate, apontaram para o fim da sociedade do trabalho, seja no sentido de perda de centralidade do trabalho na formação das identidades e subjetividades dos trabalhadores, frente a outros mundos de vida (especialmente Offe), seja questionando o papel atribuído à classe trabalhadora como sujeito da transformação social (notadamente em Gorz). Escrevendo em um momento em que as mudanças a que se referiam apenas se esboçavam, mostraram-se relativamente otimistas quanto às possibilidades de liberação do trabalho - assalariado, capitalista, alienado - e de incremento do trabalho autônomo e do tempo livre.

Contudo, vinte anos após seus escritos iniciais sobre esse tema, mais parece que a realidade não seguiu a trilha daquelas previsões. A utopia de Gorz, de uma sociedade do tempo liberado, de superação da lógica capi- 
talista e de predomínio de atividades autônomas, permanece como tal uma utopia. No decorrer do tempo, parece que acabou prevalecendo a "sociedade do desemprego" e, poderíamos acrescentar, a que conduz, também, a outras formas de inserção dos trabalhadores no mercado de trabalho, ligadas mais ao trabalho heterônomo que ao autônomo.

No caso de Offe, seus argumentos a favor de outros modos de integração social, fora da esfera do trabalho, têm sido questionados por vários autores, como se verá adiante, que defendem o fato de o trabalho permanecer ainda como um princípio organizador importante da sociedade, colocando-se, igualmente, como uma necessidade ao nível da integração ao sistema. ${ }^{12}$

Os trabalhos de Rifkin e Beck surgem em outro contexto, nos anos 90, quando o mundo do trabalho já caminhava largamente para o desemprego elevado e para a expansão de formas atípicas e precárias de trabaIho. Afirmando que as novas tecnologias permitem e, de fato, provocam redução da quantidade de trabalho necessário ao processo produtivo, endereçam sua preocupação para os impactos desfavoráveis, sobre os trabaIhadores, acarretados pelos novos modos de produzir e de organizar e gerir o trabalho. Defendem a criação de outras formas de trabalho (terceiro setor; trabalho público), capazes de absorver os indivíduos deslocados e de preencher o tempo livre dos ocupados, constituindo-se em novos centros de ação e identidade políticas.

Méda, por seu turno, retoma com vigor a questão da centralidade do trabalho, reunindo um conjunto bastante amplo de elementos para a reflexão sobre as transformações contemporâneas e suas implicações sociais, a partir das mudanças no trabalho. Não obstante entender o trabalho como um valor em vias de extinção e propugnar que se deva desencantá-lo, aliviálo das expectativas demasiado fortes que nele foram postas, reconhece o

12 Nessa linha de argumentação, análises de programas de integração de indivíduos revelam que tais experiências não têm sido exitosas. A respeito, ver Castel, 1998 e Marques, 1997, que analisam o Programa de Renda Mínima de Inserção, da França um dos mais conhecidos e estudados. Veja-se também Forrester, 1997. 
papel central que ele ainda possui em nossos dias. No seu entendimento, o trabalho dá e pode continuar a dar, mas não mais de maneira exclusiva, o acesso, para os indivíduos, à sociabilidade, à utilidade social, à integração. ${ }^{13}$ Nesse sentido, remete a discussão para a divisão entre o tempo de trabalho e o de não-trabalho, na medida em que o lugar do trabalho nas nossas vidas, especialmente quanto ao tempo de duração do trabalho, é fator primordial do desenvolvimento de outros modos de sociabilidade. Acreditando que se estaria processando o deslocamento, para o tempo livre, da centralidade hoje ainda atribuída ao trabalho, alerta para a necessidade de uma distribuição mais igualitária do tempo de trabalho, para contra-arrestar o desenvolvimento massivo do desemprego e da instabilidade.

\subsection{Trabalho e integração social}

Em uma visão alternativa às abordagens alinhadas em torno de teses que apontam para o fim do trabalho, vários autores procuram enfatizar que, não obstante o emprego assalariado esteja diminuindo, isto não significa o fim do trabalho, seja no sentido de que o tempo dedicado a essa atividade necessariamente diminuirá em proporções significativas e para a maior parte dos trabalhadores, seja na crença de que a redução do tempo de trabalho enseja a perda de seu valor social. Buscam analisar as transformações no trabalho sob o ângulo de suas implicações sociais, isto é, de seus efeitos sobre as relações de trabalho e sobre a organização social. Entendendo que nossas sociedades se estruturaram em torno do trabalho assalariado - forma típica assumida pelo trabalho no capitalismo - argumentam que o trabalho ainda se constitui em um dos vetores essenciais na

13 Cremos ser crescente o número de análises que se encaminham em direção similar à de Méda, no que se refere à permanência da centralidade do trabalho e à especulação sobre a possibilidade de essa centralidade se deslocar ao tempo livre. Nesse sentido ver Köning, 1994; Bihr, 1998; Schnapper, 1998 e Gorender, 2000. Cabe aqui destacar um aspecto extremamente relevante, relacionado à natureza do trabalho e à necessidade de transformá-lo, referido por Bihr, quando afirma que "... libertarse do trabalho necessário, reduzindo-o ao mínimo, não significa deixar de tentar transformar profundamente seus modos e conteúdos. Em outras palavras, trata-se de trabalhar menos para que todos possam trabalhar e, simultaneamente, de trabalhar de outra maneira" (Bihr, 1998, p. 189). 
estruturação das sociedades, o que os leva a refletir sobre aspectos e processos relacionados à precarização do trabalho, individualização das relações de trabalho, insegurança e vulnerabilidades, fragmentação da sociedade e integração social. Ainda dentro dessa visão, alguns autores destacam, nas relações de trabalho reestruturadas, a permanência de relações de subordinação do trabalho ao capital, muito mais do que a emergência de novas relações autônomas, de realização pessoal e de humanização do trabalho, como querem determinados autores.

Dentre os estudos que podem ser arrolados nesse campo, cabe destacar análises de três sociólogos europeus - Manuel Castells, Robert Castel e Boaventura de Sousa Santos - pela contextualização ampla e abrangente da questão do trabalho, inserindo-a no cerne das transformações do capitalismo nesse final de século XX.

\section{Manuel Castells e a individualização do trabalho}

Castells, com sua obra "A sociedade em Rede" (1999), procura caracterizar e teorizar as transformações atuais, considerando-as como uma nova etapa do capitalismo - de transição do industrialismo para o informacionalismo - marcada pela Revolução da Tecnologia da Informação, dentro da qual as mudanças no trabalho ganham destaque.

A abordagem de Castells situa o trabalho no cerne da estrutura social, o que leva o autor a sustentar que a transformação tecnológica e administrativa do trabalho e das relações produtivas dentro e em torno da empresa emergente em rede é o principal instrumento por meio do qual o paradigma informacional e o processo de globalização afetam a sociedade em geral (Castells, 1999, p. 223).

Partindo da identificação de uma tendência comum na evolução da estrutura do emprego nas últimas décadas, esse autor busca entender tendências contraditórias evidenciadas nas mudanças no trabalho, bem como apontar para variações históricas de modelos de mercado de trabalho se- 
gundo as instituições, a cultura e os ambientes políticos específicos. Considera que vivemos um período de transição, no qual o novo modelo de mercado de trabalho equivale à integração simultânea do processo de trabalho e à desintegração da força de trabalho (Castells, 1999, p. 261). Resulta daí uma configuração que se assemelha a uma colcha confusa, tecida pela interação histórica entre transformação tecnológica, política das relações industriais e ação social conflituosa (Castells, 1999, p. 262), fruto de opções econômicas e políticas de empresas e governos, que têm escolhido a via baixa no processo de transição, ou seja, a utilização dos aumentos de produtividade para obtenção de lucratividade a curto prazo.

Nesse modelo, a palavra chave é flexibilização, elemento fundamental dessa transição, que remete à organização empresarial em rede, ampliando a gama de oportunidades para as empresas em relação às estratégias para a mão-de-obra qualificada e não-qualificada, reunindo formas diversas de relações com trabalhadores e suas condições de trabalho. Em decorrência, o perfil profissional das sociedades informacionais será muito mais diverso, observando-se a convivência do trabalho assalariado com trabaIho autônomo e situações profissionais mistas.

Mas, segundo Castells, duas são as transformações fundamentais, introduzidas pela reestruturação das empresas e organizações, possibilitadas pela tecnologia da informação, pela forma organizacional da empresa em rede e estimuladas pela concorrência global: a individualização do trabalho no processo de trabalho, quanto a capacidades, condições de trabalho, interesses e projetos, e a fragmentação das sociedades, que estariam ficando cada vez mais dualizadas, polarizadas, isto é, crescendo nas extremidades superior e inferior da estrutura ocupacional e encolhendo no meio.

Tais desdobramentos representam o reverso da tendência histórica de assalariamento do trabalho e socialização da produção, predominante na era industrial, expondo os trabalhadores a uma grande vulnerabilidade fren- 
te à empresa e à deterioração generalizada de suas condições de trabalho e de vida. Ou seja, à unidade no processo de trabalho nas redes globais, contrapõe-se uma mão-de-obra que está, também em escala global, desagregada em seu desempenho, fragmentada em sua organização, diversificada em sua existência, dividida em sua ação coletiva (Castells, 1999, p. 502).

Imputando os efeitos nocivos das transformações em curso ao fato de se estar atravessando um momento de transição, Castells se revela otimista quanto às perspectivas, para a sociedade, decorrentes das novas tecnologias industriais, dado que atribui às organizações e instituições sociais a possibilidade e capacidade de desempenharem um papel importante na reversão das condições desfavoráveis à grande parcela de trabalhadores. O autor reconhece, todavia, que, se prevalecer um cenário de concorrência global irrestrita e se a regulação das relações capital-trabalho não for modificada, o endurecimento da lógica capitalista desde os anos 80 continuará a promover a polarização social, apesar da valorização profissional. Em outras palavras, sem anteparos, as forças da concorrência desenfreada no paradigma informacional levarão o emprego e a estrutura social à dualização (Castells, 1999, p. 284-5).

\section{Robert Castel e a desfiliação}

No âmbito europeu, acreditamos que a abordagem realizada por Castel é a que melhor consegue apreender o momento atual e refletir sobre seus desdobramentos presentes e "eventualidades" futuras. Embora não compartilhe a crença de que a civilização do trabalho seja uma formação social eterna, esse autor acredita que, hoje, é precisamente essa sociedade que está sendo desestabilizada e, portanto, é sobre isso que precisamos pensar. $\mathrm{O}$ fenômeno a ser perscrutado é o da instabilidade das situações de trabalho, que, com seus desdobramentos, constitui para o autor a nova questão social contemporânea a permear o debate sociológico. Esta é, no nosso entender, a contribuição central de Castel, pois, como ele 
bem destaca, remete ao problema da integração social, à medida que empurra para o primeiro plano questões vinculadas à precariedade, à vulnerabilidade, à exclusão, ou, na denominação por ele preferida, a processos de desfiliação em referência a situações de trabalho.

Para analisar a questão social atual, o autor acredita ser necessário dimensionar um novo dado contemporâneo, qual seja

a presença, aparentemente cada vez mais insistente, de indivíduos colocados em situação de flutuação na estrutura social e que povoam seus interstícios sem encontrar aí um lugar designado. Silhuetas incertas, à margem do trabalho e nas fronteiras das formas de troca socialmente consagradas - desempregados por período longo, moradores dos subúrbios pobres, beneficiários da renda mínima de inserção, vítimas das readaptaçôes industriais, jovens à procura de emprego e que passam de estágio a estágio, de pequeno trabaIho à ocupação provisória (Castel, 1998, p. 23).

Reaparece, desse modo, um novo perfil de trabalhadores sem trabaIho, integrando uma parcela da população que, no final do percurso, vê-se desqualificada também nos planos cívico e político, o que os constitui como não atores sociais, não-forças sociais.

Para examinar as transformações no trabalho, Castel vai tomar por base a situação européia, e mais precisamente, a de seu país, a França, tendo como referência a situação precedente - a sociedade salaria/ ${ }^{4}$ - uma vez que é a partir dela que as alterações podem ser observadas, medidas e analisadas. Especialmente em sua recente obra "As metamorfoses da questão social - uma crônica do salário" (1998), Castel se debruça longamente sobre a história da sociedade industrial, para reconstruir o evolver dessa

\footnotetext{
14 Para Castel, uma sociedade salarial não é apenas aquela em que a maioria da população trabalhadora é assalariada, ainda que isso seja verdade. "(...) é sobretudo uma sociedade na qual a maioria dos sujeitos sociais têm sua inserção social relacionada ao lugar que ocupam no salariado, ou seja, não somente sua renda mas, também, seu status, sua proteçâo, sua identidade. (...) a sociedade salarial inventou um novo tipo de seguridade ligada ao trabalho, e não somente à propriedade, ao patrimônio" (Castel, 1997b, p. 169).
} 
odisséia da condição de assalariado e analisar suas implicações sociais. ${ }^{15}$ Assim, resgata fenômenos dos primórdios da Revolução Industrial, como os da indigência, dos vagabundos, dos mendigos assistidos e do pauperismo, que expressariam configurações da questão social, à época, e auxiliam o autor a pensar a situação dos trabalhadores e da sociedade hoje.

Trata-se, então, de trazer à tona o frágil equilíbrio, o risco de queda em que permanecem os que se encontram nas zonas de integração caracterizadas pelo trabalho estável enquanto inserção relacional sólida, isto é, o trabalho não enquanto relação técnica de produção, mas como um suporte privilegiado de inscrição na estrutura social (Castel, 1998, p. 24). Decorre dessa interpretação a preferência do autor pelo termo desfiliação ao invés de exclusão. Falar de desfiliação - esclarece Castel - não é ratificar uma ruptura, mas reconstituir um percurso. A noção pertence ao mesmo campo semântico que a dissociação, a desqualificação ou a invalidação social. [Por outro lado], a exclusão é estanque. Designa (...) estados de privação (Castel, 1998, p. 26).

Para Castel, portanto, a nova questão social encontra-se associada ao questionamento da função integradora do trabalho na sociedade, ampliando vulnerabilidades fundadas no enfraquecimento das proteções, historicamente tecidas em torno do trabalho. Os problemas, portanto, não se resumem à retração do crescimento nem ao fim do quase-pleno-emprego. Em decorrência, na análise das metamorfoses da questão social não basta apenas considerar os que têm sido diretamente atingidos pelo desemprego ou por formas de precarização do trabalho, que se encontram às margens da sociedade salarial, mas há que considerar o conjunto da sociedade, pois, através das mutações no trabalho, está sendo posta em discussão a própria natureza dos laços e vínculos que constituem o centro das

15 Na interpretação do autor, a condição de assalariado passa por três momentos, a partir da Revolução Industrial: 1) a condição proletária, em que a remuneração assegura apenas a reprodução do trabalhador e sua família, e não há garantias legais; 2) a condição operária (modelo anos 30 a 50, na França); e 3) a sociedade salarial, na qual e da qual continuamos vivendo, não obstante as mudanças de que tem sido alvo (Castel, 1998). Para um exame da questão social hoje, no âmbito da América Latina, em suas várias dimensões, ver Wanderley, 1997. 
relações sociais e salariais. Nas palavras do autor: são sempre as orientações definidas nos centros de decisão - em matéria de política econômica e social, de gestão das empresas, de readaptações industriais, de busca de competitividade, etc. - que repercutem como uma onda de choque nas diferentes esferas da vida social (Castel, 1998, p. 34).

Analisando o contexto atual, de internacionalização do mercado em meio a exigências crescentes impostas pela concorrência e competitividade, Castel identifica que o trabalho vem sendo alvo de dois tipos de redução de custos face aos requisitos da flexibilização: de um lado trata-se de minimizar o preço da força de trabalho, de outro, de maximizar sua eficácia produtiva. ${ }^{16}$ Os desdobramentos dessa dinâmica da modernização incidem sobre a problemática do emprego através de três manifestações principais: o desemprego, a precarização do trabalho e a individualização.

O desemprego é a manifestação mais visível e o risco social mais grave, pelos efeitos desestabilizadores e dessocializantes para os que o sofrem. A precarização do trabalho, por sua vez, continua sendo a característica mais importante, embora menos espetacular. Isto porque, enfatizar essa precarização do trabalho permite compreender os processos que alimentam a vulnerabilidade social e produzem, no final do percurso, o desemprego e a desfiliação (Castel, 1998, p. 516). Ela compreende novas formas particulares de emprego, contemporâneas ao desemprego, que se traduzem em uma infinidade de situações heterogêneas, manifestando a degradação da relação salarial. ${ }^{17} \mathrm{Em}$ decorrência, inverte-se o movimento de outros períodos da sociedade industrial, quando situações particulares de emprego, próximas ao trabalho autônomo e que poderiam ser classificadas de pré-salariais, foram progressivamente absorvidas pela generalização da condição assalariada.

16 O autor refere a "flexibilidade interna à empresa, que impõe a adaptabilidade da mão-de-obra a essas situações novas e que, evidentemente, expulsa os que não são capazes de se prestar a essas novas regras do jogo, [e] a flexibilidade externa, que conduz a subcontratar fora da grande empresa uma parte das tarefas mas, em geral, sob condiçôes mais precárias, menos protegidas e com menos direitos" (Castel, 1997, p. 173).

17 De acordo com o autor, no período recente, na França, mais de 2/3 das contratações anuais o foram sob formas "atípicas", absorvendo especialmente jovens e mulheres e homens com idade entre 30 e 49 anos. 
A precarização do trabalho é vista, então, como um processo central, comandado pelas exigências tecnológico-econômicas da evolução do capitalismo moderno. É o fenômeno que suscita uma nova questão social, cujo núcleo seria novamente, tal qual o pauperismo foi na primeira metade do século XIX, a existência de inúteis para o mundo e, em torno deles, de uma nebulosa de situações marcadas pela instabilidade e pela incerteza do amanhã, que atestam o crescimento de uma vulnerabilidade de massa (Castel, 1998, p. 593).

O paradoxo é que essa situação eclode após um processo secular de construção de relações entre os indivíduos e o trabalho que, através de lutas, sofrimentos e coerções, conformou uma civilização do trabalho; a diferença a ressaltar, face aos primórdios da industrialização, é que se configura uma vulnerabilidade de após proteções. E aqui Castel desenvolve o terceiro elemento nessa metamorfose da questão social: a individualização dos comportamentos no trabalho, acarretada pelos imperativos da flexibilidade e bastante diversa das regulações coletivas da organização fordista. Tal situação, já referida por Castells, vai evocar para Castel formas pretéritas de individualização, classificadas por ele de individualismo negativo, e para as quais a figura do vagabundo - um puro indivíduo - representa-lhe o paradigma, pois são obtidas por subtração em relação ao encastramento em coletivos. Um tipo de individualismo que se declina em termos de falta - falta de consideração, falta de seguridade, falta de bens garantidos e de vínculos estáveis (Castel, 1998, p. 598).

Este individualismo se metamorfoseia hoje, na visão do autor, em individualismo de massa, mantendo o traço fundamental do individualismo negativo - o de ser um individualismo por falta de referências. ${ }^{18}$ Observa-se, assim, uma espécie de desinstitucionalização que, estendendo-se para além do trabalho, atravessa o conjunto da vida social, invertendo, assim, a trajetó-

18 Por certo, refere o autor, essa não é a única tendência verificada, pois o individualismo pode ter efeitos contrastantes sobre os grupos por ele afetados, podendo constituir-se positivamente para alguns, permitindo-lhes fugir das sujeições coletivas e expressar melhor sua identidade através de seu trabalho. 
ria de construção da sociedade salarial, de se contrapor ao individualismo negativo por meio de acréscimos a um "puro" contrato de trabalho, buscando superar a frialidade da ordem contratual, para conquistar um status.

Sintetizando o diagnóstico sobre a questão social, tal qual se apresenta nos principais países europeus - França, Alemanha e Inglaterra - a partir de dificuldades causadas pelo processo de globalização trazido pelo neo-liberalismo, Castel menciona três constatações que caracterizam formas de cristalização importantes e inquietantes da questão social: a desestabilização dos estáveis, a instalação na precariedade e um déficit de lugares ocupáveis na estrutura social.

Com base nesse quadro, o autor esboça alguns cenários possíveis, não obstante a imprevisibilidade do futuro diante da complexidade da situação colocada. O pior cenário, para ele, seria a continuidade da ruptura entre trabalho e proteção, a remercantilização completa do trabalho ou o triunfo completo do mercado (...) o triunfo da globalização (Castel, 1997b, p. 182). Além desta trajetória, o autor refere outras eventualidades possíveis: a tentativa de controlar, na margem, o processo de desagregação da sociedade salarial; um enfraquecimento do suporte salarial (desenvolvimento do terceiro setor, economias solidárias e outras atividades um tanto à margem do setor mercantil, do processo de globalização e das exigências de competitividade); e, finalmente, as previsões relativas ao fim do trabaIho, o fim da sociedade salarial - "o discurso da moda hoje em Paris" - a respeito das quais Castel mostra-se cético. ${ }^{19}$

\section{Boaventura Santos e o novo contrato social}

Enfocando as transformações econômicas e sociais em marcha desde o final do século XX, Boaventura Santos dá destaque, entre outros aspec-

\footnotetext{
19 Afirma ele: "Parece-me que a saída da civilização do trabalho é uma hipótese razoável, nenhuma formação social é eterna, mas sair da civilização do trabalho seria uma verdadeira revolução cultural, pois, há pelo menos dois séculos, toda a nossa organização social gravita em torno do trabalho. (...) Não vejo nada que hoje possa substituí-lo. Pode ser que daqui a dez ou vinte anos inventemos alguma outra coisa que não o trabalho para construir uma identidade social. Porém é no hoje que precisamos pensar, e a situação está apodrecendo" (Castel 1997b, p. 188-9).
} 
tos, às conseqüências da crise do contrato social da modernidade sobre as sociedades. Esse sociólogo português tem a peculiaridade de lançar um olhar sobre o tema a partir da realidade de uma nação situada na semiperifieria do capitalismo, como ele mesmo classifica seu país, ao contrário das discussões anteriores, que se reportam fundamentalmente aos países centrais do sistema capitalista. Desse modo, Santos alarga o espectro de contribuições para se pensar realidades como a de muitos países latino-americanos, também classificados como semiperiféricos.

Partindo do entendimento de que o contrato social é a metáfora fundadora da racionalidade social e política da modernidade ocidental (Santos, 1999, p. 34), Santos passa a examinar a realidade das duas últimas décadas do século XX. Nessa, identifica que o paradigma social, político e cultural da modernidade vem sendo alvo de muitas turbulências, apontando para uma convulsão epocale uma transição paradigmática - a crise do contrato social. Vê, na crise da contratualização moderna, a predominância estrutural dos processos de exclusão sobre os de inclusão, o que, segundo ele, aparece sob duas formas, aparentemente contraditórias: o póscontratualismo, que implica exclusão, sem perspectiva de retorno, de grupos e interesses sociais até então incluídos no contrato social - de cidadão passa-se à condição similar à de servo -, e o pré-contratualismo, que se refere ao bloqueamento de acesso à cidadania de grupos sociais antes candidatos - e com expectativas - a essa cidadania. Tais processos implicam, nos termos de Santos, conviver com a ansiedade permanente em relação ao presente e ao futuro, o desgoverno iminente das expectativas, $O$ caos permanente nos atos mais simples de sobrevivência ou de consciência (Santos, 1999, p. 46).

As transformações que acompanham esse processo decorrem do que o autor designa por consenso liberal, que se desdobra em consenso econômico liberal, em consenso do Estado fraco, em consenso democrático liberal e em consenso do primado do direito e dos tribunais, e cujo impacto mais 
decisivo se encontra no processo de dessocialização da economia, reduzindo-a à instrumentalidade do mercado e às correspondentes transações.

Buscando alternativas à proliferação da lógica de exclusão, com vistas à substituição virtuosa do velho contrato social da modernidade, Santos coloca como imperativo a construção de um novo contrato social,

muito mais inclusivo, porque deve abranger não apenas o homem e os grupos sociais mas também a natureza (...) é mais conflitual, porque a inclusão se dá tanto por critérios de igualdade como por critérios de diferença... não pode confinar-se ao espaço-tempo nacional estatal e deve incluir igualmente os espaços-tempo local, regional e global... [e, finalmente,] não assenta em distinçôes rígidas entre Estado e sociedade civil, entre economia política e cultura, entre público e privado (Santos, 1999, p. 60).

Como passos para a operacionalização desse novo contrato, o autor assinala que, em uma fase inicial, há que passar pela neutralização da lógica da exclusão decorrente do pré-contratualismo e do póscontratualismo, ao menos onde ela se mostrar mais incisiva. Nessa fase, ganha relevância o que ele propõe como sendo a redescoberta democrática do trabalho.

Esta dimensão é colocada por Santos como condição sine qua non da reconstrução da economia como forma de sociabilidade democrática, contrapondo-se a redução do trabalho a fator de produção. Há algumas condições para que isso ocorra. Primeiramente, o trabalho deve ser democraticamente partilhado, o que implica, entre outros elementos, redistribuir em nível global o estoque de trabalho disponível e fixar direitos laborais mínimos, internacionalmente, criando um denominador comum de congruência entre cidadania e trabalho em nível global. Em segundo lugar, o autor aponta para o reconhecimento do polimorfismo do trabalho, o que só será feito de forma democrática na medida em que se criar um patamar 
mínimo de inclusão para as formas atípicas de trabalho - contrapostas ao trabalho regular, em tempo integral e por tempo indeterminado (assalariamento padrão), que preponderou no curto período do fordismo, marcadamente nos países centrais - as quais se encontram em franca expansão face aos requerimentos da flexibilização das relações de trabalho. Tal proposição se opõe à utilização que vem sendo feita das formas precárias de trabalho, nas quais o trabalho é transformado em mecanismo de segregação social e mesmo de exclusão (baixos rendimentos, não-legalização, etc.) - para Santos, um ato de fascismo contratual.

Por fim, dentre as condições implicadas na redescoberta democrática do trabalho, Santos arrola a necessidade da reinvenção do movimento sindical. Para tal, esse movimento deverá reestruturar-se, apropriando-se da escala local, mas também da transnacional e atuando com o fito de recuperar a tradição solidarista e de reconstruir suas políticas de antagonismo social, erigindo-se, portanto, como um sindicalismo de mensagem integrada e alternativa civilizacional(Santos, 1999, p. 66).

Os autores enfocados nesse item ressaltam a permanência da centralidade do trabalho como elemento de organização da sociedade, de integração social e de laço social. Partindo desse ponto comum, também os aproxima a forma de visualizar a realidade contemporânea, na qual destacam os efeitos nocivos, sobre o trabalho, que têm acompanhado os processos de reestruturação produtiva e de adoção de políticas de cunho neoliberal.

Diferem, provavelmente, na ênfase atribuída à centralidade do trabalho, isto é, nas possibilidades de, por meio da regulação do trabalho, conservar ou reencontrar a capacidade de integrar os indivíduos na vida coletiva, notadamente aqueles que se encontram excluídos ou correm o risco da exclusão das proteções sociais e da valorização social associada ao fato de ser um trabalhador.

Para Castel, esse ponto é vital. Alertando para a ameaça de fratura social, aposta na regulação do trabalho como meio de tentar controlar o 
processo de desagregação da sociedade salarial. Sustenta, portanto, a centralidade do trabalho, à medida que, acredita ele, o trabalho permanece como referência dominante não somente economicamente mas também psicologicamente, culturalmente e simbolicamente, fato que se comprova pelas reações daqueles que não o tem (Castel, 1998). ${ }^{20}$

Santos também coloca ênfase no trabalho, relativizando, porém, sua centralidade, que terá de ser compartilhada com outras esferas do social (notadamente os movimentos sociais). O ponto crucial, para ele, será a construção de um novo contrato social, bastante mais inclusivo que o contrato da modernidade, pois deverá incorporar o polimorfismo do trabalho tanto quanto a natureza. ${ }^{21}$

Finalmente, a posição de Castells a esse respeito parece mais difusa. Chamando a atenção para o risco de dualização da estrutura social, aposta nas possibilidades e capacidades das instituições e organizações sociais de reverter o processo em curso, modificando a regulação das relações capital-trabalho.

\section{Para concluir, algumas reflexões}

As distintas abordagens sobre o trabalho reestruturado e as reflexões sobre as implicações sociais das mudanças em curso, analisadas neste artigo, se têm em comum o reconhecimento do fato de que a sociedade humana está atravessando um momento de grandes e profundas transformações, divergem na interpretação dos fenômenos tanto quanto nos des-

\footnotetext{
20 Um posicionamento desse tipo é compartilhado por Köning. Defendendo um papel de destaque para o trabalho remunerado na vida da maioria das pessoas, elege o desemprego como a melhor e mais desagradável prova desse fato. Para ele, o desemprego " mina... não apenas a estabilidade psíquica, como a motivação para outras atividades fora do contexto da economia de mercado. Para formular paradoxalmente: o pressuposto de poder se distanciar pelo menos um pouco da esfera do trabalho remunerado é a segura consolidação nele" (Köning, 1994, p. 159).

21 Essa posição aproxima-se da apresentada por Méda, como se viu, e também pode ser encontrada em Schnapper (1998) que, reconhecendo a centralidade do trabalho, refere a necessidade de se pensar formas de elo social distintas daquelas geradas pela participação na produção concorrencial - onde predomina o emprego assalariado -, especialmente para as populações que não pertencem a esse setor da produção.
} 
dobramentos possíveis, no futuro. É interessante perceber que todas elas, no entanto, tomam o trabalho como centro da reflexão, seja negando, questionando ou resgatando o lugar a ele atribuído na organização da sociedade. Esse controvertido debate enraíza-se no próprio turbilhão das mudanças, sugerindo a novidade que cerca os fenômenos evocados, tanto quanto denotando uma certa perplexidade face à grande e crescente diversidade que os acompanha. É com esse espírito que nos propomos tecer algumas considerações que, esperamos, possam contribuir para avançar neste debate necessário.

1. Dentre as abordagens que se propõem interpretar as transformações do trabalho atreladas à reestruturação capitalista desencadeada nas últimas décadas do século XX, cremos que aquelas que propugnam teses a respeito do fim do trabalho apressam-se demasiadamente em generalizar situações a partir de fenômenos ainda recentes e sujeitos a especificidades locais. De fato, observa-se que as análises sobre a crise e superação da sociedade do trabalho são demasiadamente centradas no contexto dos países mais avançados, tornando-se hoje problemático, senão equivocado, extrapolar, a partir de situações particulares, conclusões para outros espaços regionais. Isto porque o capital, através de seus movimentos de internacionalização, foi gradativamente incorporando as demais regiões, em um processo de constante busca de valorização, aprofundado no período recente pelo denominado fenômeno da globalização. O quadro analítico apropriado para se compreenderem os múltiplos e agudos problemas do trabalho - nacionalmente diferenciado e socialmente estratificado - deve abarcar, portanto, o irreconciliável antagonismo entre o capital social total e a totalidade do trabalho (Antunes, 1995, p. 87).

2. No tocante ao debate sobre a ampliação do tempo livre e a diminuição da jornada de trabalho, há alguns aspectos que não têm merecido a devida consideração. Primeiramente, tem-se observado que o tempo liberado do trabalho assalariado fordista vem sendo preenchido, em grande 
parte dos casos, pelo desemprego e a busca angustiante e desoladora por um trabalho, via de regra inexistente ou, na melhor das hipóteses, precário. Ademais, esta discussão deve ser travada no contexto social amplo, considerando a divisão internacional do trabalho, que concentra cada vez mais nos países ditos "em vias de desenvo/vimento" as atividades justamente "intensivas em trabalho" (Hirata, 1996). Não menos importante é ter presente que a distribuição do trabalho e do tempo livre não decorre espontaneamente do estágio da tecnologia; é uma construção histórica, objeto de luta para os trabalhadores, com vistas a uma apropriação democrática dos ganhos de produtividade e das possibilidades de gerir seus próprios destinos.

3. Atentando para os títulos e/ou manchetes que anunciam mudanças de época - adeus ao trabalho, fim dos empregos, etc. - convém analisá-los com muita cautela, contrapondo-se a uma adesão imediata, bastante ao gosto da mídia. Isto porque, ao retirar conclusões um tanto simplificadas e definitivas de processos complexos e emergentes, tais títulos parecem mais querer provocar aparente diminuição da ansiedade e da angústia em meio a um mundo eivado de inseguranças e incertezas, do que propor soluções. É com o intuito de alertar para um exame mais aprofundado desses aspectos, que Dubar (1988) enfatiza a necessidade de se lançar um olhar mais atento para trabalhos empíricos de pesquisadores, os quais, com mais dificuldades e menor repercussão na sociedade, não ratificam as tendências veiculadas por adeptos das teses do fim do trabalho. Tais estudos procuram compreender o trabaIho como centro de movimentos econômicos, sociais e pessoais, produtor de vínculo social e reconhecimento identitário e processo coletivo de resolução de problemas. Questionando as representações simplistas e abstratas sobre o que é o trabalho, tentam produzir sínteses relativas e provisórias sobre as tendências em curso, geralmente contraditórias, o que os afasta de generalizações abusivas. 
4. Ainda nessa linha de posicionamentos críticos às teses do fim do trabaIho, encontram-se estudos que optam por enfatizar, nas novas relações, a permanência da subordinação do trabalho ao capital, revelando que o capitalismo pode envolver relações de produção ambíguas e múltiplas, que existem em paralelo e inter-relacionadas com o novo foco dinâmico. Nesse sentido, a descentralização da produção, como característica distintiva da atual reestruturação capitalista, obtida via fragmentação e padronização mais profundas dos processos produtivos, é vista como uma forma particular de controlar o processo produtivo (Rojas e Palácio, 1987).

A subordinação se manifestaria de várias formas, muitas delas diversas da via clássica, do trabalho assalariado, fundada na propriedade ou não dos meios de produção. Nos processos de trabalho descentralizados, por exemplo, nos quais é comum a presença de trabalhadores autônomos e microempresários, os produtores diretos geralmente não controlam completamente a tecnologia envolvida na atividade; recebem especificações estritas de produtos e qualidades; o ritmo de trabalho, o tipo de ocupação e a remuneração (embora não seja um salário) são determinados por parte do comprador ou controlador das mercadorias e serviços produzidos (Abreu, 1986; Coli, 2000). No interior das empresas, por sua vez, as táticas de valorização do trabalho estariam relacionadas com formas severas de subordinação do trabalho, as quais se manifestariam pela coerção induzida da execução de tarefas pelos próprios trabalhadores, tanto quanto pela competição exacerbada, entre os mesmos, pela conquista da possibilidade de trabalhar, face ao desemprego elevado que mantém permanente a ameaça de perda do emprego (Saul, 1999). Portanto, o desemprego erige-se como um dos fatores importantes na aceitação, por parte da força de trabalho empregada, das atuais condições de trabalho (Meneleu Neto, 1996).

5. Para avançar neste debate, parece interessante recolher ensinamentos teórico-metodológicos de Max Weber, quando analisava, há cerca de um século atrás, um momento também de profundas mutações, associadas 
à emergência da sociedade industrial, que, para ele, estariam transformando o espírito humano a ponto de não mais se poder reconhecê-lo. Perseguindo seu enfoque, Weber propunha a investigação cuidadosa do máximo possível de grupos de trabalhadores e alertava:

mas não podemos ter nenhuma ilusão no que respeita a dois pontos fundamentais: primeiro, que um trabaIho que promova realmente esse assunto não é do tipo que se realize em poucos meses e, segundo, que só se poderá esperar os primeiros resultados autênticos quando existirem dezenas desses trabalhos (Weber, 1994, p. 235).

Portanto, a orientação de Weber, de ênfase na pesquisa empírica e de parcimônia quanto a conclusões, ganha atualidade à medida que suas preocupações podem ser aplicadas ao estágio atual de desenvolvimento do capitalismo, tanto quanto das ciências sociais, não obstante o considerável volume de pesquisas e novas linhas de investigação na área em foco. O exame de parte desse material já permite destacar que as palavras precarização e informalidade são onipresentes, geralmente empregadas para referir situações recentes, contrapostas a contextos anteriores de inserção ocupacional e social mais protegidos. Entre esses dois termos, parece que a palavra precarização expressa melhor as condições de trabalho contemporâneas, de ampliação de vulnerabilidades no trabalho. O termo informalidade, por seu turno, traz à tona situações ligadas ao denominado setor informal, sendo um conceito que, embora possa ainda explicar fenômenos que persistem, parece não mais abarcar a novidade e a enorme complexidade que cercam as situações emergentes no mundo do trabaIho. Esta percepção tem levado muitos estudiosos a dedicar esforços no sentido da construção de novos esquemas conceituais - neoinformalidade, ${ }^{22}$

22 Esse termo é usado por Sáinz (1998) para referir novas formas de inserção de trabalhadores em setores econômicos emergentes (em especial, exportação e turismo), fruto da reestruturação produtiva na América Central. 
desfiliação, processo de informalidade, ${ }^{23}$ heterogeneidades no trabalho, regime de risco, etc. - cujas teorizações estão voltadas para a apreensão e o entendimento desses fenômenos.

6. Considerando o evolver desta discussão, torna-se problemática a tese de Beck, por exemplo, de conceber a trajetória dos países ocidentais mais avançados como uma brasilianização do oeste, como se estivessem repetindo o caminho trilhado pelo Brasil, em décadas anteriores, de convívio com o chamado setor informal. Isto porque, estar-se-ia diante de uma realidade nova, na qual os próprios países tidos como subdesenvolvidos vêem-se, eles mesmos, engolfados pelas mutações que, em época de mundialização do capital, têm seu cenário ampliado para todos os recantos do planeta. Parece então que, ao invés da brasilianização do oeste, estaria gestando-se uma mundialização da precarização, em que trabaIhar à brasileira não mais se configuraria como o exercício de atividades precárias que se insertam nos interstícios da atividade econômica e cujo contingente tenderia a decrescer ou oscilar ao sabor das conjunturas econômicas. Em nossos dias, a precariedade instala-se cada vez mais no centro do processo produtivo - não mais apenas nas margens ou nos interstícios - ou, como afirma o próprio Beck, o novo centro está se tornando o centro precário (Beck, 2000, p. 70).

7. De parte dos enfoques voltados ao resgate do papel de integração social que o trabalho ainda desempenharia e que buscam advertir sobre os desdobramentos nocivos, para a sociedade, advindos das mudanças em curso, argumentamos que os aportes evocados se constituem em importantes recursos heurísticos no estudo das realidades emergentes, não obstante a proliferação de espaços sociais para a construção de identidades coletivas e para a integração social.

23 Expressão utilizada por Cacciamali (2000) que, referindo-se aos países da América Latina nos anos 90, designa "a análise de um processo de mudanças estruturais na sociedade e na economia, que redefine as relações de produção, as formas de inserção dos trabalhadores na estrutura produtiva, os processos de trabalho e as instituições" (p. 103). 
Aqui se faz mister considerar ensinamentos do sociólogo latino-americano José Nun (2000), de levar em conta as dificuldades, no campo das ciências sociais, em fazer previsões acerca do futuro, dado que o objeto de estudo dessa ciência é, ele mesmo, altamente heterogêneo e instável. Seguindo essa argumentação, Nun enfatiza a possibilidade e a necessidade de se fazerem conjecturas, no sentido de advertências acerca dos resultados indesejáveis que podem ser gerados, especialmente em contextos de mudanças profundas, se medidas necessárias não forem adotadas para evitá-los. Assim, o maior êxito a que [os cientistas sociais] podem aspirar consiste justamente em não se cumprir, isto é, em impedir que venha a ocorrer aquilo sobre o que previnem (Nun, 2000, p. 43).

Acreditamos ser este um dos sentidos primordiais que tem orientado as conjecturas e advertências realizadas por grande parte dos autores resgatados neste artigo, como também foi o que motivou nosso objetivo em sistematizar e analisar as diferentes visões sobre o trabalho em transformação. Ou seja, prevaleceu o intuito de alertar para conseqüências sociais não desejadas, abrindo possibilidades para direcionar a ação no sentido de sustar formas perversas de integração social e de exclusões, manifestas na marginalização crescente de parcelas da população e nos modos brutais de exploração da mão-de-obra que proliferam no presente moderno.

8. Enfim, como se teve oportunidade de verificar no decorrer da análise efetuada neste artigo, o lugar do trabalho na sociedade vem sendo questionado, tanto quanto resgatado, sendo alvo de amplo debate. Todavia, como afirmam muitos autores, na raiz das teses de perda de centralidade do trabaIho estariam concepções que sobrepõem diminuição do emprego assalariado e diminuição do trabalho. Se é verdade que o primeiro regride, novas formas de organização do trabalho e de inserção dos trabalhadores no mercado surgem e se multimplicam, redesenhando as relações sociais que se configuram no âmbito da produção, mas que extrapolam para as mais variadas esferas da vida social. O trabalho, mesmo que reestruturado, mantémse, portanto, como um dos vetores importantes na organização das socieda- 
des, nas relações sociais entre indivíduos e grupos, reconfigurando relações de poder e multiplicando desigualdades sociais. Sendo assim, a apreensão e a análise dessas novas formas de trabalho abrem caminhos para a reflexão a respeito da própria transformação social.

\section{Referências}

ABREU, A. R. de P. O avesso da moda - trabalho a domicílio na indústria da confecção. São Paulo: Hucitec, 1986.

ALVES, G. O novo (e precário) mundo do trabalho - Reestruturação produtiva e crise do capitalismo. São Paulo: Boitempo editorial, 2000, 365p.

ANTUNES, Ricardo. Adeus ao trabalho? Ensaio sobre as metamorfoses e a centralidade do mundo do trabalho. Campinas: Cortez, 1995.

BECK, Ulrich. Capitalismo sem trabalho. In: Ensaios FEE. Porto Alegre, FEE, ano 18, n. 1, 1997, p. 41-55.

BECK, Ulrich. Qué es la globalización? Falacias del globalismo, respuestas a la globalización. Barcelona: Paidós, 1998.

BECK, Ulrich. The brave new world of work. Cambridge, UK: Polity Press, 2000, $201 \mathrm{p}$.

BIHR, A. Da grande noite à alternativa: o movimento operário europeu em crise. São Paulo: Boitempo, 1998.

BOURDIEU, P. Contrafogos - Táticas para enfrentar a invasão neoliberal. Rio de Janeiro: Zahar Ed, 2000.

CACCIAMALI, M. C. Proceso de informalidad y sector informal - Reexamen de una discusión. Rev. Venez. de Econ. y Ciencias Sociales, v. 6, n. 3, sep.-dic., 2000, p. 95-110.

CAPPELLI, P. et al. Change at Work. New York: Oxford University Press, 1997, 276 p. 
Sociologias, Porto Alegre, ano 5, no 9, jan/jun 2003, p. 246-286

CASTEL, Robert. As metamorfoses da questão social: uma crônica do salário. Petrópolis, RJ: Vozes, 1998, 611 p.

CASTEL, Robert. As armadilhas da exclusão. In: BÓGUS, L; YAZBEK, M. C. e BELFIORE-WANDERLEY, M. (orgs.). Desigualdade e a questão social. São Paulo: EDUC, 1997a.

CASTEL, Robert. As transformações da questão social. In: BÓGUS, L; YAZBEK, M. C. e BELFIORE-WANDERLEY, M. (orgs.). Desigualdade e a questão social. São Paulo: EDUC, 1997b.

CASTELLS, Manuel. A sociedade em rede (A era da Informação: economia, sociedade e cultura; v. 1). São Paulo: Paz e Terra, 1999, 620 p.

CASTRO, Nadya Araujo. Reestruturação produtiva, novas institucionalidades e negociação da flexibilidade. Revista São Paulo em Perspectiva, F. SEADE - São Paulo, v. 11, n. 1, jan./mar, 1997.

CHESNAIS, F. Um programa de ruptura com o neoliberalismo. In: REIS A. R. et al (orgs). A crise dos paradigmas em ciências sociais e os desafios para o século XXI. Rio de Janeiro: Contraponto, CORECON, 1999, p. 77-108.

COLI, J. M. A trama da terceirização: um estudo do trabalho no ramo da tecelagem. Campinas, Editora da UNICAMP, 2000, 132 p.

CORIAT, B. Pensar pelo avesso: o modelo japonês de trabalho e organização. Rio de Janeiro: Ed. da UFRJ/Revan, 1994.

CORIAT, B. e SABOIA, J. Regime de acumulação e relação salarial no Brasil: um processo de fordização forçada e contrariada. Revista Ensaios FEE. Porto Alegre, FEE, ano 9, n. 2, 1989, p. 3-45.

DEDECCA, C.S. Dinâmica econômica e mercado de trabalho urbano. Tese de doutorado. UNICAMP, Campinas (mimeo), 1990.

DUBAR, C. O debate sobre o futuro do trabalho na França. Revista Latinoamericana de Estudios del Trabajo. (ALAST). Campinas, Editora da Unicamp, ano 4, n.8, 1988, p. 151-157. 
FITOUSSI, J.-P. e ROSANVALLON, P. A nova era das desigualdades. Portugal: Celta, 1997.

FORRESTER, V. O horror econômico. São Paulo: UNESP, 1997.

DE LA GARZA. E. La flexibilidad del trabajo en América Latina. Revista Latinoamericana de Estudios del Trabajo, São Paulo, ano 3, n. 5, 1997, p. 129-57.

GORENDER, J. Marxismo sem utopia. São Paulo: Ática, 2000, 288 p.

GORZ, André. Adeus ao proletariado: para além do socialismo. Rio de Janeiro: Forense Universitária, 1987.

HIRATA, H. Reestruturação produtiva, trabalho e relações de gênero. Águas de Lindóia, texto apresentado no II Congresso Latino-Americano de Sociologia do Trabalho, 1996.

HUMPHREY, J. O trabalho e o fordismo no Brasil. In: CASTRO, N. A. de. A máquina e o equilibrista - Inovações na indústria automobilística brasileira. Paz e Terra, 1995, p. 345-359.

KÖNIG, Helmut. A crise da sociedade de trabalho e o futuro do trabalho: crítica de um debate atual. In MARKERT, W. (org). Teorias de Educação do Iluminismo, conceitos de trabalho e do sujeito - Contribuições para uma teoria crítica da formação do homem. Rio de Janeiro: Tempo Brasileiro, 1994, p. 149-177.

LA FUENTE, M e SÁINZ, P. (2001). Participación de los pobres en los frutos del crecimiento. Revista de la CEPAL. Naciones Unidas, Santiago de Chile, dec., p. 161-70.

LIPIETZ, A. Miragens e Milagres: problemas de industrialização no terceiro mundo. São Paulo: Nobel, 1998.

MALAGUTI, M. L. Crítica à razão informal: a imaterialidade do salariado. São Paulo: Boitempo; Vitória: EDUFES, 2000, 173 p.

MARQUES, Rosa M. A proteção social e o mundo do trabalho. São Paulo: Bienal, 1997. 
Sociologias, Porto Alegre, ano 5, no 9, jan/jun 2003, p. 246-286

MATTOSO, Jorge. A desordem do trabalho. São Paulo: Scritta, 1995.

MARX, R. Processo de trabalho e grupos semi-autônomos: a evolução da experiência sueca de Kalmar aos anos 90. Revista de Administração de Empresas. São Paulo, EAESP/FGV, 32 (2), abr.-jun., 1992, p. 36-43.

MÉDA, D. New perspectives on work as value. International Labour Review, v. 135, n. 6, 1996.

MÉDA, D. O trabalho: um valor em vias de extinção. Lisboa: Fim de século Margens, 1999.

MENELEU NETO, J. Desemprego e luta de classes: as novas determinidades do conceito marxista de exército industrial de reserva. In TEIXEIRA, F.J.S e OLIVEIRA, M.A. (orgs). Neoliberalismo e reestruturação produtiva: as novas determinações do mundo do trabalho. São Paulo: Cortez; Fortaleza: Universidade Federal do Ceará, 1996, p. 75-107.

NUN. José. O futuro do emprego e a tese da massa marginal. Novos Estudos CEBRAP, n. 56, mar, 2000, p. 46-52.

OFFE, Claus. Trabalho: A categoria-chave da sociologia? RBCS, v. 4, n. 10, jun, 1989.

POCHMANN, Marcio. O trabalho sob fogo cruzado. São Paulo: Contexto, 1999, $205 p$.

RIFKIN, J. O fim dos empregos. São Paulo: Makron Books do Brasil, 1995.

ROJAS, F. y PALACIO, G. Tecnología de la información: una nueva estrategia capitalista de subordinación de los trabajadores. Cuadernos de Economia. Bogotá, Universidad Nacional de Colombia, n. 11, 1987, p. 17-73.

SÁINZ, J. P. P. Neoinformalidad e identidades laborales en Centro América. In: CASTRO A. C. e DEDECCA, C. S. Orgs. (1998). A ocupação na América Latina: tempos mais duros. São Paulo; Rio de Janeiro: ALAST, 1998, p. 107-136.

SANTOS, Boaventura de S. Reinventar a democracia: entre o pré contratualismo e o pós contratualismo. In: HELLER, A. et al. A crise dos paradigmas em 
ciências sociais e os desafios para o século XXI. Rio de janeiro: Contraponto. Corecon-RJ, 1999.

SANTOS, Boaventura de $S$. A crítica da razão indolente: contra o desperdício da experiência. São Paulo: Cortez, 2000, 415p.

SAUL. R. P. O novo horizonte ideológico do trabalho. Sociologias, ano 1, n. 1, Porto Alegre, PPGS/UFRGS, 1999, p. 276-299.

SCHNAPPER, D. Contra o fim do trabalho. Lisboa: Terramar, 1998, 123p.

SOUZA, P. R. Empregos, salários e pobreza. São Paulo: HUCITEC-UNICAMP, 1980, 193p.

STALLINGS, B e WELLER, J. El empleo en América Latina, base fundamental de la política social. Revista de la CEPAL. Naciones Unidas, Santiago de Chile, dec. 2001, p 191-210.

TONI, Míriam De e XAVIER So.; Guilherme G. de F. O mercado de trabalho gaúcho nos anos 90: A persistência de uma trajetória de precarização. Indicadores Econômicos FEE, v. 25, n. 2, Porto Alegre, 1997.

WALLERSTEIN, I. \& HOPKINS, T. K. World-systems analysis - Theory and methodology. V. 1. London: Sage Publications, 1982, cap. 1, 2, 4 e 7.

WANDERLEY, Luiz E. W. A questão social no contexto da globalização: o caso latino-americano e caribenho. In: BÓGUS, L, YAZBEK, M. C. e BELFIOREWANDERLEY, M. (org). Desigualdade e a questão social. São Paulo, EDUC, 1997.

WEBER, Max. Sociología del trabajo industrial. Madrid: Ed. Trotta, 1994, 247p.

WOOD, Stephen. O modelo japonês em debate: pós-fordismo ou japonização do fordismo. Revista Brasileira de Ciências Sociais, 17 (6), out., 1991, p. 28-42.

ZERO HORA. Gaúchos pobres são mais de 3 milhões. Porto Alegre, RBS, Caderno de Economia, 22/ago., 1999, p. 7. 
Sociologias, Porto Alegre, ano 5, no 9, jan/jun 2003, p. 246-286

\section{Resumo}

No artigo, considera-se que as transformações que têm marcado nossas sociedades a partir da crise e reestruturação do capitalismo desde as últimas décadas do século XX repercutem fortemente sobre as relações de trabalho, desordenando as relações que conformaram o Estado de Bem-Estar Social e reordenando-as sob a égide da regulação pelo mercado. Considerando o papel central atribuído ao trabalho em nossas sociedades, torna-se relevante discutir as diferentes interpretações sobre os fenômenos emergentes no mundo do trabalho - desde enfoques que apontam para o "fim do trabalho" até os que defendem a permanência da centralidade do trabalho -, refletindo sobre suas implicações sociais. Ressalta-se que o processo veloz de difusão tecnológica em voga vem precarizando as relações de trabalho, ampliando inseguranças e vulnerabilidades e sendo fonte crucial de desigualdade social. Encerra-se o artigo com reflexões sobre o evolver do mundo do trabalho, propondo um olhar crítico a posições extremadas sobre o tema e ressaltando as repercussões desfavoráveis acarretadas pelas mutações em curso, no sentido de advertir sobre conseqüências sociais não desejadas.

Palavras-chave: precarização do trabalho, relações de trabalho, centralidade do trabalho, mundo do trabalho. 